УДК 378.147

Н. С. Левицька, к. психол. н., Т. М. Децюк, к. пед. н.

\title{
РОЗВИТОК ПІДПРИЄМЛИВОСТІ У СТУДЕНТІВ РІЗНИХ СПЕЦІАЛЬНОСТЕЙ У ПОЗААУДИТОРНІЙ РОБОТІ
}

Актуальність теми дослідження. Швидкі темпи розвитку науки і техніки, процеси Євроінтеграції та глобалізації, вимагають змін підходів щодо організації процесів навчання та виховання молодого покоління.

Постановка проблеми. Формування підприємливості в процесі профресійної підготовки майбутніх фрахівців різних спеціальностей в умовах закладів вищої освіти фактично не здійснюється аудиторно. Виникає необхідність у пошуку нових форм та методів позааудиторної роботи зі студентами різних спеціальностей.

Аналіз останніх досліджень i публікацій. Проблему фрормування підприємливості розглядають в своїх працях такі науковці як М. Вебер, В. Зомбарт, Е. Фромм, О. Леонтьєв, Ф. Найт, Д. Макклелланд, К. Юнг, Д. Майерс, Й. Шумпетер, В. Рибалко.

Проблематику профресійно-педагогічної підготовки майбутніх фрахівців у позааудиторній роботі у своїх працях аналізує О. А. Кільова, Р. П. Загнибіда, О. О. Гаврилюк, Н. Г. Скрипник, В. Ю. Коваль.

Виділення недосліджених частин загальної проблеми. Проблема фрормування підприємливості у студентів різних спеціальностей у позааудиторній роботі в умовах $3 В О$ залишається маловивченою і потребує подальшого дослідження.

Постановка проблеми. Проаналізувати наукові підходи до розуміння поняття «підприємливість». Запропонувати модель формування підприємливості у студентів різних спеціальностей у позааудиторній роботі в умовах ЗВО.

Виклад основного матеріалу. Підприємливість - це одна з профресійно-особистісних якостей особистості, що дозволяє індивіду викремлювати тенденції економічних процесів не тільки окремого підприємства, але й держави в цілому, прораховувати варіанти розвитку підприємницької діяльності, креативно підходити до розробки стратеаій та прийняття тактичних рішень, а також брати відповідальність за реалізацію конкретних дій, за необхідності делегувати повноваження, працювати в команді. Для формування підприємливості у студентів різних спеціальностей необхіно створити відповідні педагогічні умови. Також важливе вдале поєднання різних форм та методів позааудиторної роботи.

Висновки. Підвищення ефективності впливу на фрормування підприємливості у студентів можливо шляхом впровадження моделі фрормування підприємливості у студентів у позааудиторній роботі в умовах ЗВО.

Ключові слова: позааудиторна робота; підприємливість; компетенції; заклад вищої освіти; профресійна підготовка.

N. M. Levytska, Candidate of Psychological Sciences T. S. Detsuk, Candidate of Pedagogical Sciences

\section{ENTREPRENEURIAL QUALITIES DEVELOPMENT WITH DIFFERENT SPECIALTIES' STUDENTS AT EXTRA-CURRICULAR WORK}

Urgency of the research. The rapid pace of development of science and technology, the processes of European integration and globalization require changes in approaches to the organization of education and training of the younger generation.

Target setting. Formation of entrepreneurial qualities in the process of professional training of future specialists of different specialties in higher education institutions isn't conducted by auditory. There is a need to find new forms and methods of non-auditing work with students of different specialties.

Actual scientific researches and issues analysis. The problem of the formation of entrepreneurial qualities is researched by M. Weber, V. Sombart, E. Fromm, A. Leontiev, F. Knight, D. McClelland, 
K. Jung, D. Myers, J. Schumpeter, V. Rybalko. The problem of professional and pedagogical training of future specialists in non-auditing work is analyzed by O. A. Kilova, R. P. Zagnibida, O. O. Gavryliuk, N. G. Skrypnyk, V. Yu. Blacksmith.

Uninvestigated parts of general matters defining. The problem of entrepreneurial qualities formation in students of different specialties in non-auditing work under University' conditions remains poorly understood and requires further research.

The research objective. An analysis of scientific approaches to understanding the concept of term "entrepreneurial qualities" is the main task of this article. In addition, we want to offer The Model of entrepreneurial qualities formation for students of different specialties in non-auditing work in conditions of University.

The statement of basic materials. The entrepreneurial quality is one of the professionallypersonal qualities of the individual. It allows to select by person the trends of economic processes not only of the individual enterprise but also of the state as a whole. Also person can determine the variants of entrepreneurial development, approach the development of strategies and tactical decisions in creative way, take responsibility for realization of concrete actions, if necessary, delegation of authority, work in a team. We need to create appropriate pedagogical conditions for forming of entrepreneurial qualities by students of different specialties. Also important aspect is a successful combination of different forms and methods of non-auditing work.

Conclusions. Increasing the effectiveness of the influence on the formation of entrepreneurial qualities in students is possible by introducing The Model of entrepreneurial qualities formation at students in non-auditing work under University conditions.

Keywords: entrepreneurial qualities; components of entrepreneurial qualities; competence; institution of higher education; extra-curricular work.

DOI: 10.25140/2412-1185-2019-1(13)-29-36

Актуальність теми дослідження. Швидкі темпи розвитку науки і техніки, а також процеси Євроінтеграції та глобалізації, вимагають змін підходів щодо організації процесів навчання та виховання молодого покоління, зокрема в умовах закладів вищої освіти. Скорочення аудиторного часу та відповідне збільшення часу на самостійну позааудиторну роботу вимагає пошуку нових форм та методів роботи з молоддю, що сприятимуть формуванню професійних та особистісних компетенцій у майбутніх фахівців, а також розвитку їх конкурентоспроможності на ринку праці.

Постановка проблеми. В сучасних умовах розвитку суспільства однією із ключових особистісних компетенцій можна визначити підприємливість. Це твердження можна обґрунтувати тим, що на сучасному етапі розвитку суспільства дана компетенція сприятиме досягненню успіху особистості, побудові успішної кар'єри та самореалізації, а отже підвищить конкурентоспроможність молодого фрахівця на ринку праці. Формування підприємливості в процесі профресійної підготовки майбутніх фахівців різних спеціальностей в умовах ЗВО фактично не здійснюється аудиторно. Тому виникає необхідність у пошуку нових форм та методів позааудиторної роботи зі студентами різних спеціальностей.

Аналіз останніх досліджень і публікацій. Проблему фрормування підприємливості та фрінансової грамотності учнів розглядають в своїх працях такі науковці як М. Вебер, В. Зомбарт, Е. Фромм, О. Леонтьєв, Ф. Найт, Д. Макклелланд, К. Юнг, Д. Майерс, Й. Шумпетер, В. Рибалко.

Проблематику професійно-педагогічної підготовки майбутніх викладачів у позааудиторній роботі у своїх працях аналізує О. А. Кільова. Особливості формування комунікативної компетентності у студентів в процесі позааудиторної роботи розглядають науковці Р. П. Загнибіда, О. О. Гаврилюк. Питанню можливостей позааудиторної діяльності в процесі особистої самореалізації студентів присвячено наукові доробки Н. Г. Скрипник. Позааудиторну роботу зі студентами як систему у ЗВО пропонує розглядати В. Ю. Коваль.

Виділення недосліджених раніше частин загальної проблеми. Питанню формуванню підприємливості у молоді в умовах загальноосвітніх навчальних закладів присвячено чимало наукових доробок. Проте проблема формування підприємливості у студентів різних спеціальностей у позааудиторній роботі в умовах ЗВО залишається маловивченою і потребує подальшого дослідження. 
Постановка проблеми. Проаналізувати наукові підходи до розуміння поняття «підприємливість». На основі досвіду Чернігівського національного технологічного університету запропонувати модель формування підприємливості у студентів різних спеціальностей у позааудиторній роботі в умовах ЗВО.

Виклад основного матеріалу. Підприємливість особистості $€$ однією 3 важливих професійно-особистісних якостей особистості. Про це свідчать національні та міжнародні програмні документи розвитку сфери освіти. Зокрема, у робочій програмі Європейської Комісії «Ключові компетентності для навчання протягом життя. Європейська довідкова система» [1] визначено основні групи компетентностей, якими має оволодіти особистість протягом життя. Однією 3 них є підприємливість, що трактується як прагнення до реалізації змін, відповідальність за прийняті рішення та діяльність, її результати. На доповнення даного визначення було розроблено Рамку підприємницької компетентності [2], що передбачає ґрунтовний аналіз компонентів підприємливості з урахуванням можливостей їх розвитку протягом всього життя людини. Українське освітнє законодавство як і стратегії реформування освіти також зорієнтовані на формування підприємливості у здобувачів освіти різних рівнів. Саме тому, під підприємливістю, у широкому сенсі, розуміють раціональну та ефективну поведінку особистості, що має своє відображення на фрінансово-економічному вимірі її життя [3]. У вузькому сенсі, розглядаються ті чи інші вміння щодо особистісної та фрінансово-економічної активності індивіда, що виливаються у конкретні результати діяльності.

Словник поведінкових компетенцій [5] трактує підприємливість як здатність формулювати нові ідеї або адаптувати і використовувати ті, що вже є, новим чи несподіваним чином для вирішення проблем; думати на перспективу, щоб визначити чи створити можливості з майбутнім їх розвитком. Автори словника визначають чотири рівня розвитку підприємливості як компетенції. Відтак, спектр досягнень варіюється від базового вдосконалення чи адаптації існуючих підходів до розуміння, орієнтування та діяльність в умовах довгострокового (стратегічного) планування 3 оцінкою можливостей та ризиків; фрормування абсолютно нестандартних інноваційних ідей та підходів.

Турецькі науковці М. Калкан та К. Кайгусуз [6], досліджуючи особливості психології підприємництва, визначають підприємливість як специфічну поведінку особистості, її ставлення та реакції до процесів і явищ у таких, що постійно змінюються умовах, задля створення нових / інноваційних підходів до вирішення існуючих проблемних питань.

Європейські науковці М. Бачігалупо, П. Кампиліс, І. П'юні та Г. Ван ден Бранде [2] пропонують розглядати «підприємливість» як компетентність, яка стосується всіх сфер життєдіяльності. На думку науковців, вона дає громадянам можливість користуватись наявними ресурсами та ідеями, а також втілювати їх на користь суспільства через започаткування власної справи чи вихід на ринок праці як найманий працівник або самозайнята особа, що може вивести підприємництво на вищий рівень та може мати культурну, соціальну або комерційну цінність.

Російський дослідник Чеберко Є. Ф. [7] визначаючи сутнісні характеристики та відмінності у поняттях «підприємництво» та «підприємливість», останню визначає як тип економічної поведінки, що пов'язана з пошуком нетрадиційних, інноваційних напрямків розвитку виробничих потужностей, економічних відносин, вибором альтернативних рішень, з ризиком та таким розвитком суспільства, що забезпечує перехід на його якісно новий рівень.

Українські психологи [8], досліджуючи загальні риси (диспозиції) підприємницького типу особистості, доходять висновку, що підприємливість являє собою комплекс професійноособистісних якостей особистості і може свідчити про рівень економічної культури індивіда.

Кожен із зазначених науковців, окрім аналізу змістовного наповнення поняття «підприємливість», також ґрунтовно досліджують його компоненти. Так, описуючи «EntreComp: Рамку підприємницької компетентності» [2] науковці виділили 15 компетентностей, які являються компонентами підприємливості, а саме: самосвідомість і самоефективність, мотивація та наполегливість, мобілізація ресурсів, фінансова та економічна грамотність, мобілізація інших осіб, взяття на себе ініціативи, планування та управління, робота з ризиками, співпраця з іншими особами, навчання через досвід, етичне та обґрунтоване мислення, оцінювання ідей, бачення, креативність, виявлення можливостей.

Український дослідник Пачковський Ю. Ф. [9] здійснюючи соціопсихологічний аналіз підприємництва в контексті тих особистісних якостей, якими має володіти особистість, для 
досягнення успіху, вказує на потребу в досягненнях (подальшому розвитку), потребу в незалежності/автономії, схильність до творчості (творчі здібності/нахили), уміння йти на розумний (зважений) ризик, а також цілеспрямованість і рішучість.

Співробітники лабораторії соціальної психології Інституту психології ім. Г.С. Костюка НАПН України, досліджують підприємливий тип особистості [8] крізь призму особистісних диспозицій (ініціативність, наполегливість, готовність до ризику, цілеспрямованість, управлінські здібності, незалежність, самовпевненість, прагнення до самореалізації, поінформованість, відповідальність).

У науковому доробку турецьких дослідників [6] означено комплекс підприємницьких якостей особистості, що були виокремлені на основі узагальнення попередніх досліджень та власних висновків. Відтак, серед 42 професійно-особистісних підприємницьких якостей першу п'ятірку займають: впевненість у собі, поміркованість, активність та енергійність, майстерність та вміння йти на ризик.

Узагальнюючи ці та інші результати аналізу сутності поняття «підприємливість», можемо запропонувати своє розуміння. Отже, підприємливість - це одна з професійно-особистісних якостей особистості, що дозволяє індивіду через аналіз сильних та слабких сторін, можливостей та ризиків викремлювати тенденції економічних процесів не тільки окремого підприємства, але й держави в цілому, прораховувати варіанти розвитку підприємницької діяльності, креативно підходити до розробки стратегій та прийняття тактичних рішень, а також брати відповідальність за реалізацію конкретних дій, за необхідності делегувати повноваження, працювати в команді.

Серед професійно-особистісних якостей, що, на нашу думку, обов'язково властиві підприємливій особистості можна виокремити такі: креативність та творчий підхід, ініціативність та відповідальність, вміння йти ризик та проявляти економічну ініціативу, незалежність та вміння працювати в команді, прагнення до змін та розуміння соціальної значущості у підприємницькій діяльності.

Особливо актуальним, на нашу думку, є розвиток підприємливості особистості на етапі професійного становлення майбутнього фахівця, незалежно від отримуваної спеціальності. Оскільки сучасний ринок праці висуває до спеціаліста вимоги досягнення результатів в умовах мультизадачності, то успішність освоєння подібного професійного та соціального досвіду буде залежати від рівня його компетентності у різних сферах і питаннях. Саме тому, аналіз «міцності» ідеї для розробки стартапу, специфіка попиту та пропозиції у конкретному продукті (товарі чи послузі), формування та взаємодія у команді однодумців, вміння презентувати себе та свою ідею, налагодження тривалої співпраці з партнерами та здійснення фандрайзингу ресурсів набір сучасних підприємливих компетенцій, що необхідні сучасному студенту.

Однак, якщо розглядати представників різних спеціальностей, то здобувачі вищої освіти фінансово-економічної спрямованості в процесі навчання отримують ґрунтовніші економічні знання та можливість їх застосування в практиці. На відміну від фінансистів та економістів, студентигуманітарії дуже часто обирають цей напрямок тому, щоб більше не мати справу з математикою. Відтак, їх рівень володіння змістовним наповненням економічних процесів та явищ є, у порівнянні 3 першими, нижчим. Проте, за рівнем креативності, пошуку нестандартних рішень і вмінням працювати в команді - соціальні працівники та юристи випереджають інших. Специфічним, на нашу думку, є підхід студентів-технарів, котрі, дуже часто, працюють над ідеєю заради самої ідеї, при цьому інколи втрачається фрінансова рентабельність та соціальна значущість.

Подібна ситуація спонукала до фрормування системного підходу щодо розвитку підприємливості майбутніх фахівців.

Відтак, розвиток даних компетенцій у здобувачів вищої освіти в Чернігівському національному технологічному університеті відбувається комплексно. По-перше, до навчальних планів їх підготовки за освітнім рівнем «бакалавр» введено економічні дисципліни (загальні уявлення щодо суті економічних явищ та процесів; фрінансово-економічні тенденції та прогнози; бізнес-планування; ціноутворення та ін.). Всі ці аспекти студенти разом із викладачами розглядають крізь призму теорії та реальних кейсів під час лекційних та семінарських занять. По-друге, активна позааудиторна робота зі студентами ЧНТУ, в т. ч., спрямована й на розвиток підприємливості особистості.

Позааудиторна робота в університеті $є$ дуалістичним процесом: з одного боку позааудиторну роботу можна визначити, як соціальний процес, оскільки вона допомагає студенту адаптуватись у суспільстві та взаємодіяти в різних життєвих ситуаціях поза навчанням, а з іншого боку - це 
індивідуальний процес, адже спрямовується на формування особистості студента, закріплення його активної громадської та професійної позиції, розвиток і реалізацію творчого та інтелектуального потенціалу.

Таким чином, позааудиторну роботу зі студентами [4] можна розглядати як організацію навчальних і виховних заходів, заснованих на індивідуальному підході, які сприяють засвоєнню професійно-важливих знань, формуванню вмінь та навичок, що $є$ невід'ємною складовою частиною професійної підготовки і здійснюється поза розкладом навчальних занять (Водовозов).

Застосування різних фрорм та методів позааудиторної роботи, які сприяють фрормуванню у студентів підприємливості, розглянемо на прикладі Чернігівського національного технологічного університету (ЧНТУ). Так, окрім, такої вже традиційної форми як дебати, в ЧНТУ застосовуються нові нетривіальні форми та методи позааудиторної роботи зі студентами, серед яких варто виділити:

1. Інтерактивні заходи в рамках проекту «Фінкультурний марафон», який реалізовується командою студентів та викладачів ННІ економіки ЧНТУ за підтримки Британської Ради. В рамках даного проекту студенти в ігровій формі (квестові завдання та вікторина) діляться фрінансовоекономічними знаннями та досвідом із учнями загальноосвітніх шкіл;

2. Тематичні тренінги - «Start-up майстерня», «Соціальне підприємництво», де учасники отримують не лише знання, а й можливість у неформальній атмосфері розробити ідею майбутнього бізнесу.

3. Конкурс «Start-up battle», що стало додатковою мотивацією до генерування ідей та розробок студентів з метою подальшого їх впровадження у життя. Команди-учасники - це змішані команди у складі яких можуть бути, як студенти, так і викладачі. Оцінювали результати представники середнього бізнесу м. Чернігова, а також досвідчені бізнес-коучі та представники громадських організацій.

4. Школа «Start-up: від ідеї до бізнес плану». Всі учасники конкурсу «Start-up battle» стали учасниками/цями даної школи. Вона представляє собою певний курс лекцій з елементами тренінгу.

5. Настільні ігри «Cashflow», «\#ГраСвітГромад», «Я-мер», «Країна гідності». Дані ігри проводяться для студентів різних спеціальностей здебільшого під час кураторських годин у групах. У студентів формуються не тільки фрінансово-економічна грамотність, а й навички стратегічного та критичного мислення, роботі в команді, ефективного управління, прогнозування, вміння приймати рішення та брати на себе відповідальність, що, на нашу думку, є складовими підприємливості.

Важливо зазначити, що науково-педагогічні працівники в процесі організації такої позааудиторної роботи зі студентами мають роль здебільшого фрасилітаторів або супервізорів, рідше тренерів, наставників. Це зумовлено специфікою підприємливості як риси особистості, яку не можливо сорормувати у директивний спосіб. Необхідно створити такі умови, які сприятимуть саморозвитку та самовдосконаленню особистості, спонукатимуть по пошуків нових шляхів і рішень. Ми пропонуємо наступні педагогічні умови розвитку підприємливості як професійноособистісної якості особистості студента в процесі позааудиторної роботи:

1) Комфортний, облаштований, сучасний простір з дружньою довірливою атмосферою. Це може бути кімната відпочинку, креативний простір в бібліотеці, студентський хаб або арт-сад під відкритим небом. Але все що оточує студента має бути естетично привабливим, сучасним та комфортним. Крім того науково-педагогічні працівники в рамках цього простору змінюють свої ролі викладача, керівника на фасилітатора, порадника, супервізора, наставника.

2) Зацікавленість сторін. Як науково-педагогічні працівники, так і студенти мають чітко розуміти свою зацікавленість у процесі. Якщо студентів зобов'язати брати участь навіть у найефективніших заходах, без внутрішньої вмотивованості не буде досягнуто зовсім ніякого ефректу. Це будуть марно витрачені час і ресурси. Це стосується і науково-педагогічних працівників. Без вмотивованості у проведенні заходів або проектів не буде досягнуть необхідного ефекту, залишиться враження «зробили для галочки».

3) Професійність організаторів. В сучасних умовах відкритого доступу до будь-якої інформації можна знайти опис тренінгу/заходу/івенту будь-якої тематики. । маючи інструментарій, деякі особи вважають що можуть без досвіду та навиків провести вдалий захід, який буде мати значний влив. Проте, саме професійність є визначальною у процесі впливу на 
свідомість особистості, формуванні їі компетенцій та навиків. Тож і керівники позааудиторної роботи мають бути кваліфікованими тренерами-фасилітаторами з відповідним досвідом та постійно займатися самовдосконаленням.

$\mathrm{Ha}$ основі усього вищезазначеного нами було розроблено модель фрормування підприємливості у студентів у позааудиторній роботі в умовах закладу вищої освіти (Рис. 1).

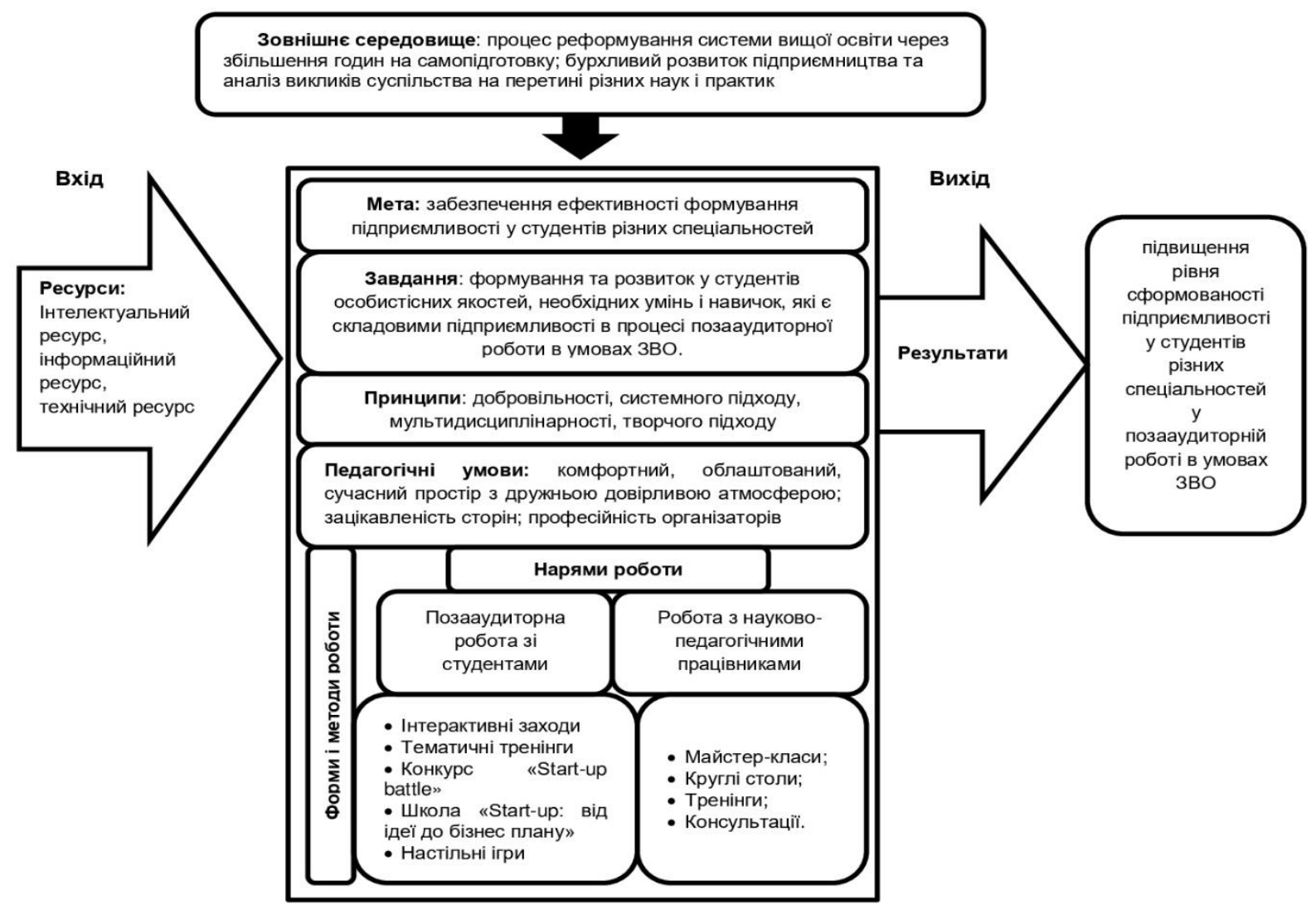

Рис. 1 Модель формування підприємливості у студентів у позааудиторній роботі в умовах закладу вищої освіти

Метою моделі є забезпечення ефрективності формування підприємливості у студентів різних спеціальностей. Завдання: формування та розвиток у студентів особистісних якостей, необхідних умінь і навичок, які є складовими підприємливості в процесі позааудиторної роботи в умовах 3 ВО.

Однією із складових запропонованої нами моделі $€$ змістовна, до якої входять принципи, у контексті яких відбувається забезпечення ефективності фрормування підприємливості у студентів різних спеціальностей: добровільності, системного підходу, мультидисциплінарності, творчого підходу.

Педагогічні умови розвитку підприємливості як професійно-особистісної якості особистості студента в процесі позааудиторної роботи становлять зміст умовної складової моделі.

Модель формування підприємливості у студентів у позааудиторній роботі в умовах закладу вищої освіти містить операційну складову, до якої входять напрями, форми та методи. Ми пропонуємо два напрями роботи. Перший напрям - це робота зі студентами, другий - 3 науковопедагогічними працівниками. Другий напрям $€$ необхідним, оскільки навики роботи у ролі тренера-фрасилітатора $€$ досить у обмеженої кількості науково-педагогічних працівників, які працюють зі студентами позааудиторно.

Перший напрям реалізується через форми та методи позааудиторної роботи зі студентами різних спеціальностей. Другий напрям має за мету методичне забезпечення науковопедагогічних працівників для формування складових компетенції підприємливість у майбутніх фахівців різних галузей у позааудиторній роботі. 
Реалізацію процесу формування професійної компетентності планується здійснювати за допомогою таких методів: освітніх семінарів, круглих столів, тренінгів, лекцій, практикумів, консультацій.

Результуюча складова моделі передбачає наявність певного рівня сформованості конкретних професійно-особистісних якостей особистості студента через позааудиторну роботу в умовах закладу вищої освіти - перехід на більш високий рівень розвитку підприємницької компетентності.

Впровадження цієї моделі в практику 3ВО, на нашу думку, сприятиме покращенню ефективності формування підприємливості у студентів різних спеціальностей.

Висновки. Проведене дослідження дало підстави для наступних узагальнень. По-перше, підприємливість - це одна з професійно-особистісних якостей особистості, що дозволяє індивіду через аналіз сильних та слабких сторін, можливостей та ризиків викремлювати тенденції економічних процесів не тільки окремого підприємства, але й держави в цілому, прораховувати варіанти розвитку підприємницької діяльності, креативно підходити до розробки стратегій та прийняття тактичних рішень, а також брати відповідальність за реалізацію конкретних дій, за необхідності делегувати повноваження, працювати в команді.

По-друге, до професійно-особистісних якостей, що властиві підприємливій особистості можна виокремити такі: креативність та творчий підхід, ініціативність та відповідальність, вміння йти ризик та проявляти економічну ініціативу, незалежність та вміння працювати в команді, прагнення до змін та розуміння соціальної значущості у підприємницькій діяльності.

По-третє, позааудиторну роботу зі студентами можна розглядати як організацію навчальних і виховних заходів, заснованих на індивідуальному підході, які сприяють засвоєнню професійноважливих знань, формуванню вмінь та навичок, що $€$ невід'ємною складовою частиною професійної підготовки і здійснюється поза розкладом навчальних занять.

По-четверте, на основі аналізу сутності та компонентів поняття «підприємливість», умов ії розвитку через позааудиторну роботу в умовах закладу вищої освіти, тих методів та прийомів, що використовуються науково-педагогічними працівниками ЧНТУ, було розроблено Модель формування підприємливості у студентів у позааудиторній роботі в умовах закладу вищої освіти.

По-п'яте, експериментальна перевірка ефективності запропонованої моделі може стати перспективою подальших наукових пошуків.

\section{1.}

1. Робоча програма Європейської Комісії «Ключові компетентності для навчання протягом життя» [Електронний ресурс]. - Режим доступу: https://zakon.rada.gov.ua/laws/show/994_975.

2. Bacigalupo, M. EntreComp: The Entrepreneurship Competence Framework / Bacigalupo, M., Kampylis, P., Punie, Y., Van den Brande, G. / Publication Office of the European Union. - Luxembourg, 2016. - P. 39; EUR 27939 EN; doi:10.2791/593884 [in English].

3. Концепція нової української школи [Електронний ресурс] - Режим доступу: https://www.kmu.gov.ua /storage/app/media/reforms/ukrainska-shkola-compressed.pdf.

4. Vodovozov, V. The model of extracurricular work with students of engineering specialties / V. Vodovozov, Z. Raud \& T. Detsiuk // Advanced Education, 10. - 2018. - P. 55-61. DOl: 10.20535/2410-8286.143528 [in English].

5. Словарь поведенческих компетенций [Електронний ресурс] - Режим доступу: http://www. hivreforminaction.org/wp-content/uploads/2016/07/Competency-Dictionary_RUS_HIVRiA.pdf.

6. Kalkan, M. The Psychology of Entrepreneurship [Electronic resource] / M. Kalkan, C. Kayguzus. - Access mode: [https://www.intechopen.com/books/entrepreneurship-born-made-and-educated/the-psychology-of-entrepreneurship]. [in English].

7. Чеберко Е.Ф. Предпринимательство и преприимчивость. Национальный потенциал предприимчивости. [Електронний ресурс] / Е. Ф. Чеберко. - Режим доступу: http://vestnik.osu.ru/2006_2/22.pdf.

8. Економічна соціалізація молоді: соціально-психологічний аспект / загальна ред. В. В. Москаленко К. : Український центр політичного менеджменту, 2008. 336 с.

9. Пачковський, Ю. Ф. Психологія підприємництва: навч. посібник / Ю. Ф. Пачковський. - 3-є вид. - К. : Каравелла, 2007. -401 c.

\section{References}

1. Robocha prohrama Yevropeiskoi Komisii «Kliuchovi kompetentnosti dlia navchannia protiahom zhyttia» [European Commission Work Program "Key competencies for lifelong learning"]. zakon.rada.gov.ua. Retrieved from https://zakon.rada.gov.ua/laws/show/994_975 [in Ukrainian].

2. Bacigalupo, M., Kampylis, P., Punie, Y., Van den Brande, G. (2016). EntreComp: The Entrepreneurship Competence Framework. Luxembourg: Publication Office of the European Union. DOl:10.2791/593884 [in English].

3. Kontseptsiia novoi ukrainskoi shkoly [. Concept of the new Ukrainian school]. www.kmu.gov.ua. Retrieved from https://www.kmu.gov.ua/storage/app/media/reforms/ukrainska-shkola-compressed.pdf [in Ukrainian]. 
4. Vodovozov, V., Raud, Z. \& Detsiuk, T. (2018). The model of extracurricular work with students of engineering specialties. Advanced Education, 10, 55-61. DOI: 10.20535/2410-8286.143528 [in English].

5. Slovar povedencheskykh kompetentsyi [Dictionary of Behavioral Competences]. www.hivreforminaction.org. Retrieved from http://www.hivreforminaction.org/wp-content/uploads/2016/07/Competency-Dictionary_RUS_HIVRiA.pdf [in Ukrainian].

6. Kalkan, M., Kayguzus, C. (2011). The Psychology of Entrepreneurship. www.intechopen.com. Retrieved from https://www.intechopen.com/books/entrepreneurship-born-made-and-educated/the-psychology-of-entrepreneurship [in English]

7. Cheberko, E. F. (2006). Predprinimatelstvo i prepriimchivost. Natsionalnyy potentsial predpriimchivosti [Entrepreneurship and acceptability. National entrepreneurial potential]. vestnik.osu.ru. Retrieved from http://vestnik.osu.ru/2006_2/22.pdf [in Russian].

8. Moskalenko, V. V. (Eds.). (2008). Ekonomichna sotsializatsiia molodi: sotsialno-psykholohichnyi aspekt [Economic socialization of youth: socio-psychological aspect]. Kyiv: Ukrainskyi tsentr politychnoho menedzhmentu [in Ukrainian].

9. Pachkovskyi, Yu. F. (2007). Psykholohiia pidpryiemnytstva [Psychology of Entrepreneurship]. (3rd ed.). Kyiv: Karavella [in Ukrainian]

Надійшла 21.03.2018

Бібліографічний опис для цитування :

Левицька, Н. С. Розвиток підприємливості у студентів різних спеціальностей у позааудиторній роботі / Н. С. Левицька, Т. М. Децюк // Проблеми соціальної роботи: філософрія, психологія, соціологія. - 2019 - № 1 (13) - С. 29 -36. 